\title{
Chemical composition and sensory analysis of peanut pastes elaborated with high-oleic and regular peanuts from Argentina
}

\author{
By Cecilia G. Riveros, ${ }^{a}$ M. G. Mestrallet, ${ }^{a}$ V. Nepote ${ }^{b}$ and N. R. Grosso ${ }^{a}$ \\ a Química Biológica, Facultad de Ciencias Agropecuarias (UNC), \\ IMBIV-CONICET, CC 509, 5000 Córdoba, Argentina \\ b ICTA, Facultad de Ciencias Exactas, Físicas y Naturales, \\ IMBIV-CONICET, Córdoba, Argentina. \\ ('Corresponding authors: e-mail nrgrosso@agro.unc.edu.ar)
}

\section{RESUMEN}

\begin{abstract}
Análisis químico y sensorial de pastas de cacahuete elaboradas a partir de cacahuete alto oleico y convencional de Argentina.
\end{abstract}

El objetivo del trabajo fue determinar la composición química, atributos sensoriales y la aceptabilidad de pastas de cacahuete elaboradas a partir del cultivar alto oleico, Granoleico (GO-P), en comparación con el cultivar convencional, Tegua (T-P), de cacahuetes desarrollados en Argentina. GO$\mathrm{P}$ presentó mayor contenido de aceite $(50.91 \%)$ que T-P (48.95\%). GO-P y T-P no mostraron diferencias en los contenidos de cenizas y carbohidratos. T-P presentó mayor contenido de proteínas $(27.49 \%)$ que GO-P (26.68\%). GO-P mostró contenidos significativamente mayores de ácido oleico y menores de ácido linoleico $(78.50 \%$ y $4.60 \%$, respectivamente) que T-P (45.80\% y $33.30 \%$, respectivamente). Además, GO-P mostró mayor porcentaje de ácido eicosenoico y menor en ácido palmítico que T-P. Los análisis de aceptabilidad no presentaron diferencias significativas entre las muestras GO-P y T-P. En el análisis descriptivo, GO-P mostró mayor intensidad en el atributo de textura "aceitosidad". Los otros atributos sensoriales no presentaron variaciones significativas entre las muestras de pasta de cacahuete. GO-P y T-P tienen una marcada diferencia en la composición de ácidos grasos. Sin embargo, no hay diferencias en aceptabilidad y análisis sensorial descriptivo entre las muestras de pastas de cacahuete excepto por el atributo "aceitosidad".

PALABRAS CLAVE: Aceptabilidad - Alto oleico - Manteca de cacahuete - Sensorial.

\section{SUMMARY}

Chemical composition and sensory analysis of peanut pastes elaborated with high-oleic and regular peanuts from Argentina.

The objective of this work was to determine the chemical composition, sensory attributes and consumer acceptance of peanut pastes prepared with the high-oleic cultivar, Granoleico (GO-P), in comparison with the regular cultivar, Tegua (T-P), of peanuts grown in Argentina. GO-P had higher oil contents $(50.91 \%)$ than T-P $(48.95 \%)$. GO-P and T-P did not show differences in ash and carbohydrate contents. T-P exhibit higher protein content (27.49\%) than GO-P (26.68\%). GO-P had significantly higher oleic and lower linoleic contents $(78.50 \%$ and $4.60 \%$, respectively) than T-P $(45.80 \%$ and $33.30 \%$, respectively). In addition, GO-P showed higher eicosenoic acid and lower palmitic acid percentages than T$P$. The consumer acceptance analysis did not show significant differences between samples of GO-P and T-P. In the descriptive analysis, GO-P showed a higher intensity rating in the oiliness texture attribute than in T-P. The other sensory attributes did not show significant variations between the peanut paste samples. GO-P and T-P have a significant difference in fatty acid composition. However, there were no differences in consumer acceptance and descriptive analysis between samples of peanut pastes except for the oiliness attribute.

KEY-WORDS: Acceptability - High oleic - Peanut butter - Sensory.

\section{INTRODUCTION}

Peanut-containing foods have high consumer acceptance because of their unique roasted peanut flavor. Peanuts are continually applied for the preparation of new and improved food products (Woodroof, 1983). A large proportion of peanut production in the world is destined to domestic foods such as peanut butter, snack products, confections and roasting peanut products showing positive results in relation to consumer acceptance and sensory and chemical stability (Ahmed and Young, 1982; Mestrallet et al., 2004; Nepote et al., 2006a, b; Nepote et al., 2008). The rest of the peanut production is utilized as an edible oil source of high quality (Ahmed and Young, 1982).

Peanuts contain high percentages of oil (45$54 \%$ ) and protein (25-31\%) (Savage and Keenan, 1994; Grosso et al., 2002). The presence of these components is important in the end-products of the peanut industry because they became an important contribution to the human diet in many countries for their nutritional benefits to consumers. Due to their high oil content, peanuts are rich in energy but are susceptible to developing rancidity and off-flavors through lipid oxidation because of their composition rich in unsaturated fatty acid (approximately $80 \%$ ), with $40-50 \%$ and $30-40 \%$ of the oil being oleic and linoleic acids, respectively (Frankel, 2005). Although linoleic acid 
is an essential component for human nutrition, it is susceptible to lipid oxidation (Nawar, 1996). Researchers from USA have described peanut lines called high oleic peanuts with $80 \%$ oleic acid and $2-3 \%$ linoleic acid which had improved oil oxidative stability in the products elaborated with them (Mugendi et al., 1998; Pattee et al., 2002). High-oleic peanut products like roasted peanuts (Nepote et al., 2006a) and fried-salted peanuts (Nepote et al., 2006b) prepared with Argentinean cultivars showed longer stability during storage. However, the chemical and sensory properties of peanut pastes prepared with high oleic peanuts have not been studied in depth, especially those prepared with Argentinean peanut varieties.

Peanut butter is a dispersion of peanut oil in peanut solids released through the grinding of roasted mature, shelled and blanched peanuts. For a product to be labelled as peanut butter, it should contain $90 \%$ peanuts while the remaining $10 \%$ is comprised of sweeteners, seasonings, emulsifiers, and/or stabilizers (U.S. FDA, 2002). Peanut butter has extensive use as a spread for bread and crackers. It is used as an ingredient in sandwiches, cookies, confectioneries, in flavoring foods, wafers, patties, bars, and other snacks (Woodroof, 1983). Peanut paste, which is $100 \%$ ground peanuts, is used in a variety of industrial food recipes and is available from processors (American Peanut Council, 2008).

The objective of this work was to determine the chemical composition, sensory attributes and consumer acceptance of peanut pastes prepared with a high-oleic cultivar (Granoleico) in comparison with a regular cultivar (Tegua) of peanuts developed in Argentina.

\section{MATERIALS AND METHODS}

\subsection{Materials}

Sound and mature seeds of blanched peanuts (Arachis hypogea L.) type Runner "Granoleico" and "Tegua", size 40/50 kernels per oz (2007 crop) were provided by the company Lorenzati, Ruetsch \& Cia from Ticino, Córdoba, Argentina.

\subsection{Methods}

\section{Preparation of samples}

For preparing "Granoleico" (GO-P) and "Tegua" (T-P) peanut pastes, blanched peanuts were roasted at $140{ }^{\circ} \mathrm{C}$ in an oven (Memert, model 600 , Schwabach, Germany) for $30 \mathrm{~min}$. Peanuts were heated to a medium roast measured as an average Hunter color Lightness (L) value of $50 \pm 1.0$ (Johnsen et al., 1988). Peanuts were ground using a colloid mill (COLMIL Mod. AD 50 VR, Munro, Buenos Aires, Argentina). Upon completion of the formulation process, the cooled product was distributed into $350 \mathrm{~g}$ plastic jars.
Determination of oil, ash, protein, and carbohydrate contents of the peanut products

Peanut pastes were examined for moisture, lipid, protein, ash and carbohydrate contents. The moisture content was determined by the method 27.005 (AOAC, 1980). Oil was extracted for 16 hours with petroleum ether (boiling range $30-60^{\circ} \mathrm{C}$ ) in a Soxhlet apparatus. Lipid percentage was determined by weight difference. Ash and nitrogen contents were determined according to the AOAC methods 27.009 and 27.007, respectively (AOAC, 1980). Ash was performed by incineration in a muffle furnace at $525^{\circ} \mathrm{C}$. The nitrogen content was estimated according to the Kjeldahl method and converted to protein percentage by using the conversion factor 5.46 (method 27.007, AOAC, 1980). Carbohydrate content was estimated by the difference of the other components using the following formula (Mestrallet et al., 2004): carbohydrate content $=100 \%-(\%$ protein $+\%$ oil $+\%$ ash).

\section{Fatty acid composition of peanut paste}

Fatty acid methyl esters were prepared from peanut paste oils (GO-P and T-P) by transmethylation with a solution of $3 \%(\mathrm{w} / \mathrm{v})$ sulphuric acid in methanol as previously described (Grosso et al., 2000). The fatty acid methyl esters of total lipids were analyzed on a Perkin Elmer Clarus 500 gas-liquid chromatograph (Waltham, Massachusetts, USA) equipped with a flame ionization detector (FID). A Varian CP-Wax 52 CB capillary column (30m, 0.25mm, 0.25um \# CP8713) (Lake Forest, CA, USA) was used. Column temperature was programmed from $180^{\circ} \mathrm{C}$ (held for $1 \mathrm{~min})$ to $230{ }^{\circ} \mathrm{C}\left(20{ }^{\circ} \mathrm{C} / \mathrm{min}\right.$ rate $)$. The carrier (nitrogen) had a flow rate of $3.8 \mathrm{~mL} / \mathrm{min}$. The separated fatty acid methyl esters were identified by comparing their retention times with those of authentic samples which were purchased from Sigma Chemical Co (St Louis, MO, USA). Quantitative fatty acids analysis was performed using heptadecanoic acid methyl ester (Sigma Chemical Co.) as internal standard.

\section{Sensory Methods}

a) Consumer Analysis. The panelists $(\mathrm{n}=94)$ were from Córdoba (Argentina) and were recruited according to the following criteria: a) ages between 18 and 65, b) non-smokers, c) people without food allergies and d) people who consumed roasted peanuts and/or peanut products at least twice a week. For sample evaluation, $10 \mathrm{~g}$ of the peanut paste samples were placed into plastic cups with lids coded with 3 digit random numbers. Samples consisting of GO-P and T-P were served to every panellist (Resurreccion, 1998). Samples were presented to panellists in random order during the test day. Samples were served with water and 
paper ballots on a plastic tray. Panellists were instructed to consume the whole sample (a teaspoon of peanut paste) and rinse their mouths with water between samples to minimize any residual effect (Grosso and Resurreccion, 2002). A 9-point hedonic scale ranging from $1=$ dislike extremely to $9=$ like extremely was used to evaluate acceptance from the GO-P and T-P samples for the attributes of color, flavor and texture (Peryam and Pilgrim, 1957).

b) Descriptive Analysis. A total of 10 trained panellists ( 6 female and 4 male) participated in the descriptive analysis of peanut products (GO-P and T-P). All panellists were selected according to the following criteria: a) people with natural dentition, b) people without food allergies, c) non-smokers, d) people between the ages of 18-64, e) people who consume roasted peanuts and/or peanut products at least once a month, f) people available for all sessions, g) people interested in participating, and h) people able to verbally communicate their observations regarding the product (Plemmons and Resurreccion, 1998). Before being qualified, all panellists showed a perfect score in a taste sensitivity test and the ability to identify 5 of 7 commonly found food flavors.

All 10 panellists had 6 years of experience evaluating peanut products. The panellist were trained and calibrated in 4 training sessions for 4 days for evaluating peanut pastes. Each training session lasted $3 \mathrm{~h}$. Descriptive analysis test procedures as described by Meilgaard et al. (1991), Grosso and Resurreccion (2002) and Nepote et al. (2006a) were used to train the panellists. A "hybrid" descriptive analysis method consisting of the Quantitative Descriptive Analysis (Tragon Corp., Redwood City, Calif., U.S.A.) and the Spectrum ${ }^{T M}$ Analysis Methods (Sensory Spectrum, Inc., Chatham, N.J., U.S.A.) were used by the panellists for evaluating samples. A $150 \mathrm{~mm}$ unstructured line scale was used (Plemmons and Resurreccion, 1998). A list of definitions and a sheet with warm-up and reference intensity ratings (Table 1) were developed during the training sessions (Grosso and Resurreccion, 2002; Mestrallet et al., 2004). The attribute definitions were based on peanut lexicon (Johnsen et al., 1988).

All samples were evaluated in partitioned booths under fluorescent light at room temperature. Ten grams of product sample were placed in plastic cups with lids coded with 3 digit random numbers. The final lists of warm-up and reference intensity ratings and definitions (Table 1) were posted in the booths for all test sessions (Grosso and Resurreccion, 2002). The panellists were instructed to familiarize themselves with the reference standard intensities (Table 1) and then to evaluate the sensory attributes from the peanut paste samples. A complete randomized block design was used for testing samples. The data were registered on paper ballots.

\subsection{Statistical Analysis}

The data were analyzed using the InfoStat software, version 1.1 (Facultad de Ciencias Agropecuarias, Universidad Nacional de Córdoba). All analyses were performed in three repetitions. Each repetition corresponded to a different production lot provided by the peanut company, Lorenzti, Ruetsch \& Cia (Ticino, Córdoba, Argentina). Means and standard deviations were calculated. Analysis of variance and Duncan test were used to detect significant differences ( $\alpha=$ 0.05) in consumer responses, sensory attribute ratings and chemical analysis measurements.

\section{RESULTS AND DISCUSSION}

\subsection{Oil, protein, ash, and carbohydrate contents in the peanut pastes}

The oil, protein, ash and carbohydrate contents of the peanut pastes (GO-P and T-P) are presented in Figure 1. The product prepared with the high-oleic cultivar, Granoleico (GO-P) showed significant differences $(\alpha=0.05)$ in oil and protein contents with respect to those prepared with a regular cultivar, Tegua (T-P). GO-P had higher oil content (50.91\%) than T-P (48.95\%). GO-P and T-P did not show difference in ash and carbohydrate contents. T-P exhibited higher protein contents $(27.49 \%)$ than GO-P (26.68\%). Ozcan and Seven (2003) reported different results in peanut butter prepared with ÇOM and NC-7 varieties of regular peanuts from Turkey. Protein, lipid and ash contents were $35.07 \%, 24.55 \%$ and $1.86 \%$, respectively for ÇOM peanut butter; $32.93 \%, 18.67 \%$ and $2.04 \%$, respectively for NC-7 peanut butter.

\subsection{Fatty acid composition of peanut pastes}

The fatty acid percentages of GO-P and T-P are shown in Table 2. The major components of both peanut pastes were oleic, linoleic, and palmitic acids.

As it was expected in the fatty acid composition, GO-P had significantly higher oleic contents and lower linoleic contents $(78.50 \%$ and $4.60 \%$, respectively) than T-P $(45.80 \%$ and $33.30 \%$, respectively). Others authors reported similar results in the oleic and linoleic contents in regular (Özcan and Seven, 2003) and high-oleic peanut pastes (Isleib et al., 2006). Similar results in these fatty acid contents were also found in other peanut products like roasted peanuts (Nepote et al. 2006a) and friedsalted peanuts (Nepote et al., 2006b) elaborated with high-oleic and regular peanut lines from Argentina.

The differences in oleic and linoleic contents between GO-P and T-P translated into differences for oleic/linoleic ratio (O/L), iodine value and polyunsaturated/saturated ratio (PUFA/SFA). GO-P showed a significantly higher $\mathrm{O} / \mathrm{L}$ ratio (17.06) and a lower polyunsaturated/saturated fatty acid ratio (0.32) than T-P $(\mathrm{O} / \mathrm{L}=1.38$ and PUFA/SFA $=1.74)$. lodine value was also lower in GO-P (77) than T-P 
Table 1

Definitions of attributes, standard references and warm-up intensity ratings used in the descriptive analysis of peanut pastes

\begin{tabular}{|c|c|c|c|c|}
\hline Attribute $^{a}$ & Definition & Reference & $\begin{array}{l}\text { Reference } \\
\text { Intensity }^{\text {b }}\end{array}$ & $\begin{array}{l}\text { Warm-up } \\
\text { Intensity }\end{array}$ \\
\hline \multicolumn{5}{|l|}{ Appearance } \\
\hline 1- Brown Color & $\begin{array}{l}\text { The intensity or the strength of } \\
\text { brown color from light to dark } \\
\text { brown. }\end{array}$ & $\begin{array}{l}\text { Hazelnut and cocoa } \\
\text { spread butter }\end{array}$ & 120 & 44 \\
\hline 2- Uneven Color & $\begin{array}{l}\text { The amount of speckles in the } \\
\text { peanut paste coming from residual } \\
\text { particles of peanut skins. }\end{array}$ & $\begin{array}{l}\text { Hazelnut and cocoa } \\
\text { spread butter }\end{array}$ & 75 & 15 \\
\hline 3- Glossiness & $\begin{array}{l}\text { The appearance associated with } \\
\text { the amount of light reflected by the } \\
\text { product surface. }\end{array}$ & $\begin{array}{l}\text { Hazelnut and cocoa } \\
\text { spread butter }\end{array}$ & 100 & 115 \\
\hline \multicolumn{5}{|l|}{ Aromatics } \\
\hline 4- Roasted Peanutty & $\begin{array}{l}\text { The aromatic associated with } \\
\text { medium roasted peanuts. }\end{array}$ & $\begin{array}{l}\text { Dry roasted } \\
\text { peanuts }^{e}\end{array}$ & 44 & 55 \\
\hline 5- Oxidized & $\begin{array}{l}\text { The aromatic associated with } \\
\text { rancid fats and oils. }\end{array}$ & Rancid peanuts & 75 & 1 \\
\hline 6- Cardboard & $\begin{array}{l}\text { The aromatic associated with } \\
\text { wet cardboard. }\end{array}$ & Moist cardboard & 45 & 5 \\
\hline 7- Burnt & $\begin{array}{l}\text { The aromatic associated with } \\
\text { over roasted peanuts }\end{array}$ & $\begin{array}{l}8 \mathrm{~g} \text { of Coffee } \\
\text { in } 250 \mathrm{~mL} \text { distilled } \\
\text { water }\end{array}$ & 80 & 20 \\
\hline 8- Raw/Beany & $\begin{array}{l}\text { The aromatic associated with } \\
\text { uncooked or raw peanuts. }\end{array}$ & Raw peanuts ${ }^{\mathrm{g}}$ & 65 & 30 \\
\hline \multicolumn{5}{|l|}{ Tastes } \\
\hline 9- Sweetness & $\begin{array}{l}\text { Taste on the tongue associated } \\
\text { with sucrose solutions. }\end{array}$ & $\begin{array}{l}2 \% \text { sucrose solution } \\
5 \% \text { sucrose solution } \\
10 \% \text { sucrose solution }\end{array}$ & $\begin{array}{r}20 \\
50 \\
100\end{array}$ & 25 \\
\hline 10- Salty & $\begin{array}{l}\text { Taste on the tongue associated } \\
\text { with sodium chloride solutions. }\end{array}$ & $\begin{array}{l}0.2 \% \mathrm{NaCl} \text { solution } \\
0.35 \% \mathrm{NaCl} \text { solution } \\
0.5 \% \mathrm{NaCl} \text { solution }\end{array}$ & $\begin{array}{l}25 \\
50 \\
85\end{array}$ & 10 \\
\hline 11-Sourness & $\begin{array}{l}\text { Taste on the tongue associated with } \\
\text { acid agents such as citric acid } \\
\text { solutions. }\end{array}$ & $\begin{array}{l}0.05 \% \text { citric acid solution } \\
0.08 \% \text { citric acid solution } \\
0.15 \% \text { citric acid solution }\end{array}$ & $\begin{array}{r}20 \\
50 \\
100\end{array}$ & 5 \\
\hline 12- Bitterness & $\begin{array}{l}\text { Taste on the tongue associated with } \\
\text { bitter solutions such as caffeine. }\end{array}$ & $\begin{array}{l}0.05 \% \text { caffeine solution } \\
0.08 \% \text { caffeine solution } \\
0.15 \% \text { caffeine solution }\end{array}$ & $\begin{array}{r}20 \\
50 \\
100\end{array}$ & 15 \\
\hline \multicolumn{5}{|l|}{ Feeling factors } \\
\hline 13- Astringent & $\begin{array}{l}\text { The puckering or drying sensation on } \\
\text { the mouth or tongue surface }\end{array}$ & $\begin{array}{l}8 \mathrm{~g} \text { of } \text { Coffee }^{f} \text { in } 250 \mathrm{~mL} \\
\text { distilled water }\end{array}$ & 60 & 35 \\
\hline \multicolumn{5}{|l|}{ Texture $^{\mathrm{h}}$} \\
\hline 14- Oiliness & $\begin{array}{l}\text { Degree to which free oil is perceived } \\
\text { in the mouth. }\end{array}$ & $\begin{array}{l}\text { Hazelnut and cocoa } \\
\text { spread butter }^{d}\end{array}$ & 40 & 55 \\
\hline 15- Adhesiveness & $\begin{array}{l}\text { Force required for removing the } \\
\text { material that adheres to the palate } \\
\text { during the normal eating process. }\end{array}$ & $\begin{array}{l}\text { Hazelnut and cocoa } \\
\text { spread butter }\end{array}$ & 45 & 80 \\
\hline 16- Graininess & $\begin{array}{l}\text { Degree to which grains or granules are } \\
\text { perceived in the mouth. }\end{array}$ & $\begin{array}{l}\text { Hazelnut and cocoa } \\
\text { spread butter }^{d}\end{array}$ & 25 & 35 \\
\hline
\end{tabular}

\footnotetext{
${ }^{\text {a }}$ Attributes listed in order as perceived by panellists.

${ }^{b}$ Intensity ratings are based on $150 \mathrm{~mm}$ unstructured line scales.

${ }^{c}$ Standard Peanut paste (lightness value, $L=50 \pm 1$ ) prepared with roasted peanuts (Type Runner, Blanched).

'Hazelnut and cocoa spread butter, "®Nutella", FERRERO S. p. A. P. le. P. FERRERO, Alba, Italia.

e Dry roasted peanuts, type Runner, JL SA, Ticino, Córdoba, Argentina.

${ }^{\dagger}$ Coffee, Nescafé $\circledast$ Clásico, Nestlé Argentina S.A. Buenos. Aires, Argentina.

${ }^{g}$ Raw peanuts, size 40/50, Lorenzati, Ruetsch y CIA, Ticino, Córdoba, Argentina.

${ }^{\mathrm{h}}$ The texture descriptors and their corresponding definitions were adapted from Civille and Szczesniak (1973) and

Muego-Gnanasekharan and Resurreccion, 1992.
}

(98). In addition, GO-P exhibited higher percentage of eicosenoic acid $(2.51 \%)$ but lower percentages of palmitic acid $(5.77 \%)$ than T-P $(1.72 \%$ and $9.93 \%$, respectively). The other fatty acids did not differ significantly between GO-P and T-P.

Özcan and Seven (2003) showed $1.51 \mathrm{O} / \mathrm{L}$ ratio in the peanut butter elaborated with the regular cultivar NC-7 while ÇOM had $2.07 \mathrm{O} / \mathrm{L}$ ratio. Nepote et al. (2006a) showed a similar O/L ratio in roasted peanuts elaborated with peanuts from Tegua (1.4) and the Granoleico (17.2) cultivars. Other authors (Andersen et al., 1998; Isleib et al., 2006) found O/L ratios between $16-28$ and $1-3$ for high-oleic and normal peanut genotypes, respectively.

Little variation was observed in the fatty acid composition between GO-P and T-P which could 


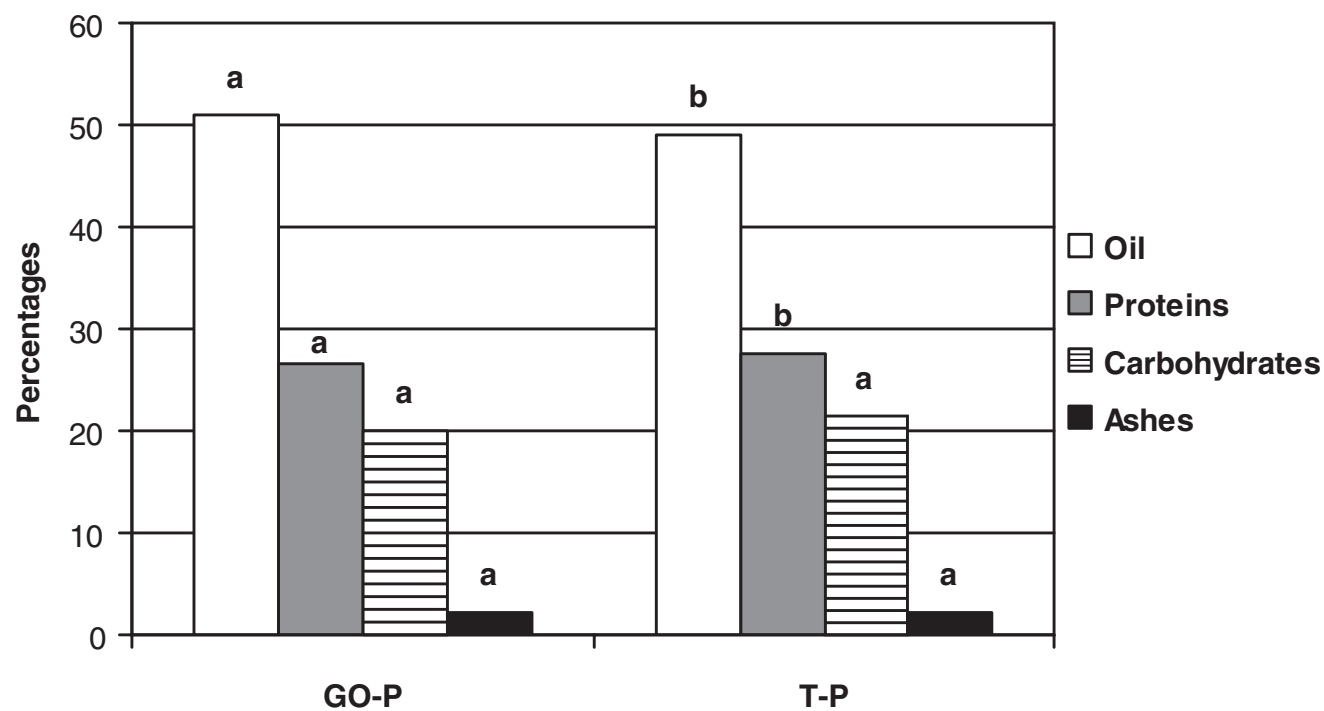

Figure 1

Oil, protein, carbohydrate and ash percentages ( $\mathrm{g} / 100 \mathrm{~g}$ peanuts) in Granoleico and Tegua peanut pastes (GO-P and T-P). Bars of the same component with different letters among peanut products are significantly different at $\alpha=0.05$.

probably be due to differences in climatic conditions, soil moisture and environment temperature during maturation of the peanut seeds (Norden et al., 1987; Casini et al., 2003). However, the genetic effect between these varieties was the main cause for the content differences in oleic and linoleic acids.

\subsection{Consumer analysis}

In this study, the consumer test was conducted for detecting differences between products. The answer percentages for each point in the hedonic scale of the color, flavor and texture acceptance and general means from consumer tests in GO-P and T$P$ are presented in Table 3. Significant differences
( $\alpha=0.05)$ in consumer acceptance among the products (GO-P and T-P) were not found. In general, the products had consumer acceptances closer to the point 7 "like moderately" for color and flavor attributes and the point 5 "neither like nor dislike" for texture attribute in a hedonic scale of nine points. The general acceptance means for the color attribute were $7.12 \pm 0.52$ and $6.91 \pm 0.42$ for GO$\mathrm{P}$ and T-P, respectively. For the flavor attribute, the acceptance was $6.71 \pm 0.25$ and $6.51 \pm 0.35$ in GO-P and T-P, respectively.

Other studies of overall acceptance in other peanut products such as roasted peanuts (Nepote et al., 2006a) and fried-salted peanuts (Nepote et al., 2006b) prepared with a high-oleic and regular

Table 2

Fatty acid composition of Tegua and Granoleico peanut pastes (T-P and GO-P)

\begin{tabular}{lcc}
\hline Fatty acids $^{\mathrm{a}}$ & \multicolumn{2}{c}{ Composition (g/100g fatty acids) } \\
\cline { 2 - 3 } & T-P & GO-P \\
\hline Saturated & $19.18 \pm 0.96^{\mathrm{a}}$ & $14.39 \pm 0.72^{\mathrm{b}}$ \\
Palmitic acid (C16:0) & $9.93 \pm 0.45^{\mathrm{a}}$ & $5.77 \pm 0.25^{\mathrm{b}}$ \\
Stearic acid (C18:0) & $2.64 \pm 0.12$ & $2.52 \pm 0.12$ \\
Arachidic acid (C20:0) & $1.47 \pm 0.09$ & $1.31 \pm 0.12$ \\
Behenic acid (C22:0) & $3.14 \pm 0.26$ & $2.76 \pm 0.25$ \\
Lignoceric acid (C24:0) & $2.00 \pm 0.11$ & $2.03 \pm 0.12$ \\
& & \\
Monounsaturated & $47.52 \pm 2.38^{\mathrm{a}}$ & $81.01 \pm 4.05^{\mathrm{b}}$ \\
Oleic acid (C18:1) & $45.80 \pm 2.42^{\mathrm{a}}$ & $78.50 \pm 3.94^{\mathrm{b}}$ \\
Eicosenoic acid (C20:1) & $1.72 \pm 0.12^{\mathrm{a}}$ & $2.51 \pm 0.25^{\mathrm{b}}$ \\
Polyunsaturated & $33.30 \pm 1.69^{\mathrm{a}}$ & $4.60 \pm 0.28^{\mathrm{b}}$ \\
Linoleic acid (C18:2) & $33.30 \pm 1.69^{\mathrm{a}}$ & $4.60 \pm 0.28^{\mathrm{b}}$ \\
Oleic/Linoleic ratio & $1.38 \pm 0.07^{\mathrm{a}}$ & $17.06 \pm 0.85^{\mathrm{b}}$ \\
IY (iodine value) & $98 \pm 4.90^{\mathrm{a}}$ & $77 \pm 3.85^{\mathrm{b}}$ \\
Polyunsaturated/Saturated ratio & $1.74 \pm 0.09^{\mathrm{a}}$ & $0.32 \pm 0.02^{\mathrm{b}}$ \\
\hline
\end{tabular}

${ }^{a}$ Means follow by different letters within each row are significantly different at $\alpha=0.05$. 
Table 3

Answer percentage for each point in hedonic scale and general means of the color, flavor and texture acceptance from consumer tests of Tegua and Granoleico peanut pastes (T-P and GO-P)

\begin{tabular}{|c|c|c|c|c|c|c|}
\hline & \multicolumn{6}{|c|}{ Answer percentage (\%) in consumer test } \\
\hline & \multicolumn{2}{|c|}{ COLOR } & \multicolumn{2}{|c|}{ FLAVOR } & \multicolumn{2}{|c|}{ TEXTURE } \\
\hline & T-P & GO-P & T-P & GO-P & T-P & GO-P \\
\hline 1. Dislike Extremely ${ }^{a}$ & 0.00 & 0.00 & 0.00 & 0.00 & 4.26 & 1.06 \\
\hline 2. Dislike Very Much ${ }^{a}$ & 0.00 & 0.00 & 2.13 & 0.00 & 6.38 & 6.38 \\
\hline 3. Dislike Moderately ${ }^{a}$ & 1.06 & 0.00 & 4.26 & 1.06 & 9.57 & 13.83 \\
\hline 4. Dislike Slightly ${ }^{a}$ & 4.26 & 2.13 & 11.70 & 7.45 & 23.40 & 22.34 \\
\hline 5. Neither Like nor Dislike ${ }^{a}$ & 13.83 & 10.64 & 9.57 & 12.77 & 13.83 & 8.51 \\
\hline 6. Like Slightly ${ }^{a}$ & 21.28 & 20.21 & 26.60 & 27.66 & 21.28 & 24.47 \\
\hline 7. Like Moderately ${ }^{a}$ & 27.66 & 29.79 & 20.21 & 26.60 & 11.70 & 10.64 \\
\hline 8. Like Very Much a & 23.40 & 30.85 & 19.15 & 18.09 & 5.32 & 11.70 \\
\hline 9. Like Extremely ${ }^{a}$ & 8.51 & 6.38 & 6.38 & 6.38 & 4.26 & 1.06 \\
\hline Total & 100.00 & 100.00 & 100.00 & 100.00 & 100.00 & 100.00 \\
\hline General mean ${ }^{\mathrm{b}, \mathrm{c}}$ & $6.91 \pm 0.42$ & $7.12 \pm 0.52$ & $6.51 \pm 0.35$ & $6.71 \pm 0.25$ & $5.25 \pm 0.31$ & $5.38 \pm 0.45$ \\
\hline
\end{tabular}

${ }^{a}$ Hedonic scale of 9 points (Peryam and Pilgrim, 1957).

${ }^{\mathrm{b}}$ There were not significantly different at $\alpha=0.05$.

General means corresponding to scores from all consumer answers in a hedonic scale of 9 points.

peanut cultivars did not report significant differences in consumer acceptance of peanut products. In general, these products had consumer acceptances close to the points 6 "like slightly" and 7 "like moderately", respectively, using a 9 point hedonic scale. In honey roasted peanuts prepared with normal Runner type peanuts from Argentina, these products had an overall acceptance close to 6 (like slightly) in a hedonic scale of 9 points (Mestrallet et al., 2004). In roasted peanuts coated with prickle pear pod and "algarrobo" syrups prepared with normal Runner type peanuts from Argentina, the results of the consumer test exhibited good acceptability for flavor, color and texture acceptance in these products showing values higher than the point 3 (neither like nor dislike) in a hedonic scale of 5 points (Nepote et al., 2008).

With respect to the answer percentage for each point of the hedonic scale during the consumer test, the highest percentages were observed in the points 7 "like moderately" and 8 "like very much" for color, 6 "like slightly" and 7 "like moderately" for flavor and 4 "dislike slightly" and 6 "like slightly" for texture attributes in both peanut pastes. There were no significant differences in these answer percentage between GO-P and T-P. Considering the answer percentage in each point of the hedonic scale and the means of acceptance scores, it was evident that the differences in the chemical composition of peanut pastes (GO and T) did not have an effect on consumer acceptability of this products.

\subsection{Descriptive Analyses}

Sixteen sensory attributes were described by the trained panellists during the descriptive analysis of peanut pastes. The attributes were the followings: brown color, uneven color, glossiness, roasted peanutty, oxidized, cardboard, burnt and raw/beany flavors, sweetness, salty, sourness, bitterness, astringent, oiliness, adhesiveness and graininess (Table 4). The mean values of the intensities of sensory attributes from the descriptive analysis in GO-P and T-P are presented in Table 1.

Differences between GO-P and T-P for intensity ratings of the sensory attributes were not statistically detectable $(\alpha=0.05)$ except for the oiliness attribute. The intensity of oxidized and cardboard flavors in GO-P and T-P did not show differences between GO-P and T-P because the analyzed products were fresh without storage. Pattee et al. (2002) reported differences in these attributes. Oxidized and cardboard flavors are sensory attributes associated with chemical changes occurring during lipid oxidation when the peanut product is stored for a long time (Frankel, 2005). Previous reports confirmed that the higholeic trait is associated with less oxidative off-flavors (Mugendi et al., 1998; Pattee et al., 2002; Nepote et al., 2006b) during storage.

T-P showed lower intensity ratings than GO-P in oiliness texture (52.70 and 54.14, respectively). The differences found in oiliness texture between T-P and GO-P were probably due to the lower oil content T-P (48.95\%) than in GO-P (50.91\%). Lee and Resurreccion (2001) found swallow oiliness rates from 62.58 to 68.16 (scale of $0-150 \mathrm{~mm}$ ) in normal peanut butter. Oiliness after swallowing is crucial to the quality of peanut butter, as excessive oiliness is undesirable to the consumer. The oiliness intensity detected in this study was lower than Lee and Resurreccion (2001) reported for peanut butter prepared with American peanuts.

Roasted peanutty flavor is the attribute used to characterize the typical roasted peanut flavor in peanut products (Johnsen et al., 1988). This attribute did not show significant differences between GO-P (57.60) and T-P (57.00) samples. Similar results were reported by Isleib et al. (2006). Johnsen et al. (1988) developed a basic lexicon for 
Table 4

Means of the sensory attribute intensity ratings from the descriptive analysis of Tegua and Granoleico peanut pastes (T-P and GO-P)

\begin{tabular}{lcc}
\hline Sensory Attributes ${ }^{\mathrm{a}, \mathrm{b}}$ & T-P & GO-P \\
\hline Appearance & & \\
Brown Color & $47,84 \pm 1,36$ & $48,46 \pm 3,20$ \\
Uneven Color & $17,13 \pm 3,20$ & $17,34 \pm 2,16$ \\
Glossiness $^{\mathrm{a}, \mathrm{b}}$ & $114,30 \pm 4,17$ & $115,28 \pm 4,40$ \\
Aromatics & & \\
Roasted Peanutty & $57,06 \pm 3,08$ & $57,60 \pm 3,12$ \\
Oxidized & $3,23 \pm 2,11$ & $2,78 \pm 1,56$ \\
Cardboard & $4,84 \pm 0,75$ & $4,24 \pm 1,58$ \\
Burnt & $25,10 \pm 3,07$ & $26,17 \pm 2,16$ \\
Raw/Beany & $22,29 \pm 6,00$ & $23,50 \pm 2,29$ \\
Tastes & & \\
Sweetness & $24,38 \pm 2,32$ & $23,65 \pm 2,62$ \\
Salty & $10,21 \pm 0,62$ & $10,29 \pm 1,33$ \\
Sourness & $6,48 \pm 2,04$ & $5,81 \pm 3,07$ \\
Bitterness & $15,87 \pm 1,43$ & $16,06 \pm 2,24$ \\
Feeling factors & & \\
Astringent & $35,54 \pm 3,44$ & $36,53 \pm 3,15$ \\
Texture & & \\
Oiliness & & \\
Adhesiveness & $52,70 \pm 3,48^{\mathrm{a}}$ & $54,14 \pm 1,95^{\mathrm{b}}$ \\
Graininess & $83,54 \pm 6,17$ & $83,30 \pm 8,47$ \\
\hline antensity ratings are based on 150 mm unstructured line scales. & \\
${ }^{\mathrm{b}}$ Means follow by different letters within each row are significantly different at $\alpha=0.05$.
\end{tabular}

the description of peanut flavor. The lexicon is intended to provide a communication means about sensory characteristics from peanuts among the peanut grower, the peanut industry, the peanut researcher and peanut manufacturers. Roasted peanutty flavor can be attributed to the presence of pyrazines (Buckholz and Daun, 1981; Crippen et al., 1992). Bett and Boylston (1992) found that roasted peanutty flavor intensity and alkylpyrazines decreased in stored roasted peanuts. Brannan et al. (1999) and Nepote et al. (2006b) also found that roasted peanutty flavor decreased in stored roasted peanuts. Meilgaard et al. (1991) reported a roasted peanutty intensity of 7 in a scale of $1-15$ points equivalent to 70 in a scale of $0-150$ points measured by a trained panel in roasted peanuts from America. Grosso and Resurreccion (2002) found that the roasted peanutty intensity was 67 and 63 in Roasted Peanuts and Cracker Coated Peanuts, respectively, also in peanut products prepared with American peanuts. The roasted peanut flavors in the peanut pastes prepared with Argentinean peanuts reported in this study were lower than those results reported in other studies performed in roasted peanuts prepared with American peanuts.

\section{CONCLUSIONS}

The results of this work indicate that both peanut pastes (GO-P and T-P) prepared with peanut from Argentina have good acceptability for the consumers in colour and flavour. Both varieties,
GO-P and T-P have a high difference in fatty acid composition due to the high concentration in oleic acid in GO-P. However, consumers could not find difference in the acceptance from peanut pastes prepared with peanuts from Granoleico and Tegua cultivars even in descriptive analysis, trained panellist could not detect significant difference in the intensity rating of the sensory attributes except for oiliness. In addition, peanut products derived from high-oleic cultivars have the advantage for possessing higher stability and preservation during storage.

\section{ACKNOWLEDGEMENTS}

This work was supported by CONICET and SECYT-UNC.

\section{REFERENCES}

Ahmed EH, Young CT. 1982. Composition, quality, and flavor of peanuts, in Pattee HE, Young CT (Ed.). Peanut Science and Technology, American Peanut Research and Education Society Inc., Yoakum, TX, USA, pp. 655-688.

American Peanut Council. 2008. About The Peanut Industry. Value-Added Products. Available: http://www. peanutsusa.com/USA/index.cfm?fuseaction=home. $p$ age\&pid=12, December, 152008.

Andersen PC, Hill K, Gorbet DW, Brodbeck BV. 1998. Fatty acids and amino acid profiles of selected peanut cultivars and breeding lines. J. Food Comp. Anal. 11, 100-111. 
AOAC. 1980. Official Methods of Analysis. Horwitz W (Ed.), 13th ed, Association of Official Analytical Chemists, Washington, DC, USA, pp. 435-440.

Bett KL, Boylston TD. 1992. Effect of storage on roasted peanut quality, in St. Angelo AJ (Ed.) Lipid Oxidation in Food, ACS Symposium Series 500, American Chemical Society, Washington, DC, USA, pp. 322-343.

Brannan GL, Koehler PE, Ware GO. 1999. Physicochemical and sensory characteristics of defatted roasted peanuts during storage. Peanut Sci. 26, 44-53.

Buckholz LL, Daun H. 1981. Instrumental and sensory characteristics of roasted peanut flavor volatiles, in Teranishi R, Barrera-Benitez H (Ed.) Quality of Selected Fruits and Vegetables, ACS Symposium Series 170, American Chemical Society, Washington, DC, USA, pp. 163-181.

Casini C, Dardanelli JL, Martínez MJ, Balzarini M, Borgogno CS, Nassetta M. 2003. Oil quality and sugar content of peanuts (Arachis hypogaea) grown in Argentina: their relationship with climatic variables and seed yield. J. Agric. Food Chem. 51, 6309-6313.

Crippen KL, Vercellotti JR, Lovegren NV, Sanders TH. 1992. Defining roasted peanut flavor quality, Part 2, Correlation of GC volatiles and sensory flavor attributes, in Charalambous G (Ed.) Food Science and Human Nutrition, Elsevier Science Publisher BV, Amsterdam, pp. 211-227.

Frankel EN. 2005. Lipid Oxidation, 2nd ed, The Oily Press. Bridgewater, England, pp. 1-470.

Grosso NR, Nepote V, Guzmán CA. 2000. Chemical composition of some wild peanut species (Arachis L.) seeds. J. Agric. Food Chem. 48, 806-809.

Grosso NR, Nepote V, Giannuzzo N, Guzmán CA. 2002. Composición porcentual de ácidos grasos y de esteroles de algunos genotipos de especies silvestres de maní. Anales de la Asociación Química Argentina (Journal of the Argentine Chemical Society) 90 (4/6), 45-53.

Grosso NR, Resurreccion AVA. 2002. Predicting consumer acceptance ratings of cracker-coated and roasted peanuts from descriptive analysis and hexanal measurements. J. Food Sci. 67, 1530-1537.

Isleib TG, Pattee HE, Sanders TH, Hendrix KW, Dean LO. 2006. Compositional and sensory comparisons between normal and high-oleic peanuts. J. Agric. Food Chem. 54, 1759-1763.

Johnsen PB, Civille GV, Vercellotti JR, Sanders TH, Dus CA. 1988. Development of a lexicon for the description of peanut flavor. J. Sensory Studies 3, 9-17.

Lee CM, Resurreccion AVA. 2001. Improved correlation between sensory and instrumental measurements of peanut butter texture. J. Food Sci. 67, 1939-1949.

Meilgaard M, Civille GV, Carr BT. 1991. Selection and Training of Panel Members, in Sensory Evaluation Techniques, 2nd ed, CRC Press Inc, Boca Raton, Florida, USA, pp. 135-235

Mestrallet MG, Carnacini L, Días MJ, Nepote V, Ryan L, Conci S, Grosso NR. 2004. Honey Roasted Peanuts and Roasted Peanuts from Argentina. Sensorial and Chemical Analyses. Grasas y Aceites 55, 401-408. Spain.

Mugendi JB, Sims CA, Gorbet DW, O'Keefe SF. 1998. Flavor stability of high oleic peanuts stored at low humidity. J. Amer. Oil. Chem. Soc. 75, 21-25.

Nawar WW. 1996. Lipids, in Fennema O (Ed) Food chemistry. 3rd ed, Marcel Dekker, New York, USA, pp. 255-264.

Nepote V, Mestrallet MG, Accietto RH, Galizzi M, Grosso NR. 2006a. Chemical and sensory stability of roasted high-oleic peanuts from Argentina. J. Sci. Food Agric. 86, 944-952.

Nepote V, Mestrallet MG, Grosso NR. 2006b. Oxidative stability in fried-salted peanuts elaborated with higholeic and regular peanut from Argentina. I. J. Food Sci. and Tech. 41, 900-909.

Nepote V, Mestrallet MG, Olmedo RH, Ryan LC, Conci S, Grosso NR. 2008. Chemical Composition and Sensory Analysis of Roasted Peanuts Coated with Prickly Pear and Algarrobo Pod Syrups. Grasas y Aceites 59, 174-181.

Norden AAJ, Gorbet DW, Knauff DDA, Young CT. 1987. Variability in Oil Quality among Peanut Genotypes in the Florida Breeding Program. Peanut Sci. 14, 7-11.

Özcan M, Seven S. 2003. Physical and chemical analysis and fatty acid composition of peanut, peanut oil and peanut butter from ÇOM and NC-7 cultivars. Grasas y Aceites 54, 12-18.

Pattee HE, Isleib TG, Moore K, Gorbet DW, Giesbrecht FG. 2002. Effect of the high-oleic trait and paste storage variables on sensory attribute stability of roasted peanuts. J. Agric. Food Chem. 50, 7366-7370.

Peryam DR, Pilgrim FJ. 1957. Hedonic scale method of measuring food preferences. Food Technol. 11, 9-14.

Plemmons LE, Resurreccion AVA. 1998. A warm-up sample improves reliability of responses in descriptive analysis. J. Sensory Studies 13, 359-376.

Resurreccion AVA. 1998. Consumer Sensory Testing for Product Development, Aspen Publisher Inc. Gaithersburg, Maryland, USA.

Savage GP, Keenan JI. 1994. The composition and nutritive value of Groundnut kernels, in Smart J (Ed.).The Groundnut Crop, Chapman and Hall. London. UK, pp. 173-213.

U.S. Food and Drug Administration-Center of Devices and Radiological Health. 2002. Code of Federal Regulations. Title 21-Food and Drugs.-Sec. 164.150 Peanut butter. Washington D.C. Available at http://www.accessdata.fda.gov/scripts/cdrh/cfdocs/cf CFR/showCFR.cfm ?FR5164.150. Accessed July 17, 2004.

Woodroof JG. 1983. Peanuts. Production, Processing, Products, 3th ed, AVI Publishing Company Inc., Westport, CT, USA, pp. 8-10.

Recibido: 4/2/09 Aceptado: 9/3/09 